The Bible in the Sixteenth Century 


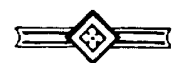

Duke Monographs in

Medieval and Renaissance Studies I I

Editorial Committee

Arthur B. Ferguson, Edward P. Mahoney, Chairman

Lee W. Patterson, David C. Steinmetz

Bruce W. Wardropper, Ronald G. Witt,

Caroline Bruzelius, Joan M. Ferrante 


\section{The Bible in the Sixteenth Century}

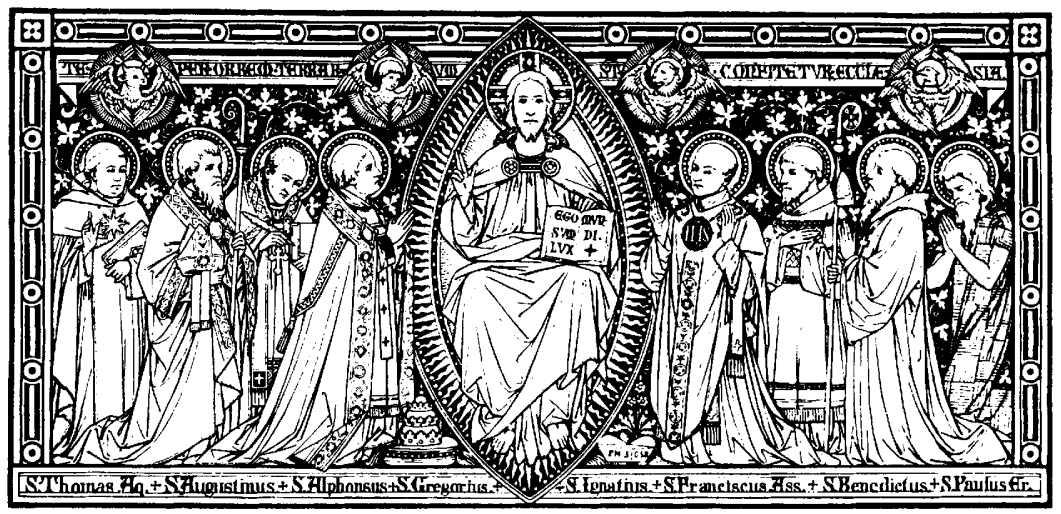

Duke University Press

Durham and London

I 990 
(C) 1990 Duke University Press

First printing in paperback, 1996

All rights reserved

Printed in the United States of America

on acid-free paper $\infty$

Library of Congress Cataloging-in-Publication data appear on the last printed page of this book 